\title{
INTERPRETATIONS OF THE CONCEPT OF SUSTAINABILITY AMONGST THE UK'S LEADING FOOD AND DRINK WHOLESALERS
}

\section{TUMAČENJA KONCEPTA ODRŽIVOSTI MEĐU VODEĆIM VELEPRODAVAČIMA HRANE I PIĆA U UJEDINJENOM KRALJEVSTVU}

\section{Peter Jones ${ }^{a}$, Daphne Comfort ${ }^{b}$, David Hillier}

a) University of Gloucestershire, The Park, Cheltenham, UNITED KINGDOM, pjones@glos.ac.uk

b) University of Gloucestershire, The Park, Cheltenham, UNITED KINGDOM, dcomfort1@glos.ac.uk

c) University of South Wales, Pontypridd, Wales, UNITED KINGDOM, illier@yahoo.com

\begin{abstract}
Purpose - The aim of this paper is to provide an exploratory review of the interpretations of the concept of sustainability amongst the UK's leading food and drinks wholesalers, as revealed by the sustainability agendas and achievements reported on their corporate websites.

Design/Methodology/Approach - The paper begins with short introductions to sustainability, corporate sustainability and sustainability reporting, and food and drinks wholesaling within the UK. The empirical material for the paper is drawn from reports and information posted on the leading food and drinks wholesalers' corporate websites.
\end{abstract}

Findings and implications - There are marked variations in the extent to which the UK's leading food and drinks wholesalers reported and provided information on their sustainability agendas and achievements. These agendas and achievements embraced a wide range of environmental, social and economic issues, but the reporting process had a number of weaknesses that undermined its transparency and credibility. The authors also argue that the leading food and drinks wholesalers' definitions of, and commitments to, sustainability are

\section{Sažetak}

Svrha - Cilj je rada dati izviđajni pregled tumačenja koncepta održivosti među vodećim veleprodavačima hrane i pića u Ujedinjenom Kraljevstvu kako to pokazuju njihovi programi i postignuća o kojima izvještavaju na službenim web stranicama.

Metodološki pristup - Rad započinje kratkim uvodom o održivosti, održivosti poduzeća, izvještavanju o održivosti te veleprodajnom poslovanju sektora hrane i pića u Ujedinjenom Kraljevstvu. Empirijski materijal za rad dobiven je iz izvještaja i informacija koje su postavljene na web stranice vodećih veleprodavača hrane i pića.

Rezultati i implikacije - Postoje značajne razlike u opsegu u kojem vodeći veleprodavači hrane i pića u Ujedinjenom Kraljevstvu izvještavaju i pružaju informacije o svojim programima održivosti i postignutim rezultatima. Ti programi i postignuća obuhvaćaju širok raspon pitanja vezanih uz okoliš, društvo i gospodarstvo, ali sam proces izvještavanja ima brojne nedostatke koji potkopavaju njegovu transparentnost i kredibilitet. Isto tako, autori pokazuju kako su određenje i predanost održivosti vodećih veleprodavača hrane i pića prije svega potaknuti poslovnim imperativima kao osnovnom bri- 
principally driven by business imperatives as by any fundamental concern to maintain the viability and integrity of natural and social capital.

Limitations - The paper is a preliminary review of the sustainability agendas and achievements publicly reported by the UK's leading food and drinks wholesalers.

Originality - Within the food and drinks supply chain, wholesalers have a pivotal role at the interface between producers, manufacturers, retail and service providers, and as such they can play in promoting sustainability. However, the role of the UK's wholesale sector in addressing sustainability has received scant attention in the academic literature, so this paper will interest academics and students in business management and marketing.

Keywords - corporate sustainability, UK food and drinks wholesalers, economic growth gom za održavanjem opstanka i integriteta prirodnog i društvenog kapitala.

Ograničenja - Rad je preliminarni pregled programa održivosti i postignuća o kojima su javno izvještavali vodeći veleprodavači hrane i pića u Ujedinjenom Kraljevstvu.

Doprinos - U opskrbnom lancu hrane i pića veleprodavači imaju središnju ulogu na sučelju između proizvođača, maloprodaje i pružatelja usluga te kao takvi mogu promovirati održivost. Međutim, uloga veleprodajnog sektora u održivom poslovanju u Ujedinjenom Kraljevstvu malo je zastupljena u akademskoj literaturi pa će ovaj rad zainteresirati znanstvenike i studente poslovnog upravljanja i marketinga.

Ključne riječi - održivost poduzeća, veleprodaja hrane i pića u Ujedinjenom Kraljevstvu, ekonomski rast 


\section{INTRODUCTION}

Retailers, and more particularly a small number of large superstore and supermarket operators, are the major players in the distribution of food and drinks within the UK; they have been described as "the engine of the food distribution system" (Stedman \& Faulk, 2009). During the past decade, all the leading food retailers have increasingly publicly recognized the impact of their operations on the environment, on society and on the economy, and they have pursued and publicized policies and programs designed to manage these impacts as part of their developing corporate sustainability strategies. These policies and programs and the achievements associated with them, which are usually captured and published annually in sustainability reports, have attracted increasing attention from researchers in business and management (e.g. Jones, Comfort, Hillier \& Eastwood, 2005; Chkanikova \& Mont, 2015; Jones, Comfort \& Hillier, 2015a). While the large retailers are the dominant players in the UK's food distribution system, wholesalers also play an important, albeit lesser role, and they supply over 400,000 businesses within the UK; despite the growing power of the large retailers, they "remain an indispensable part of the supply process for many thousands of small retailers" (Newman \& Cullen, 2002, p. 346). A wholesaler has been defined as "an organization which buys goods and resells them either to the retailers, who will sell them onto the public, or to companies, who will use the goods for the production of other goods and services" (Baron, Davies \& Swindley, 1991, p. 208). More specifically, the UK's food and drink wholesalers play "pivotal roles at the interface between producers, importers, manufacturers, retail and service providers" (Euro Commerce, 2014) and such they, much as their retail counterparts in the food and drink distribution system, have an important role to play in promoting sustainability. However, the role of wholesalers in addressing and promoting sustainability within the wholesale food and drinks sector within the UK has received scant attention in the academic literature; where sustainability has been addressed, it has usually related to limited elements of the overall wholesale distribution system. A study of a small number of specialist food producers in the sparsely populated Scottish Borders by Ilbery and Maye (2005, p. 331), for example, made limited reference to the role of wholesalers in the food distribution system and concluded that the producers were not particularly sustainable. From an individual product perspective, Yakovleva, Sparks and Sloan (2010) looked to develop sustainability indicators for the food chain using the example of potato supply chains in the UK. With this in mind, the aim of this paper is to provide an exploratory review of the interpretations of the concept of sustainability amongst the UK's leading food and drinks wholesalers, as revealed by the sustainability agendas and achievements reported on their corporate websites. The paper begins with brief reviews of the growing interest in, and commitment to, corporate sustainability, sustainability reporting, and of food and drinks wholesaling within the UK. This is followed by an exploratory review of the most recent sustainability reports and information published by the UK's leading food and drinks wholesalers and by some reflections on current approaches to sustainability within the UK's food and drinks wholesale industry.

\section{THE CONCEPT OF SUSTAINABILITY}

The ideas underpinning sustainability are not new (Gruber, 2013), but the concept began to attract increasing attention from the 1980s onwards, following the publication of the World Conservation Strategy (International Union for Conservation of Nature and Natural Resources, 1980) and Our Common Future (World Commission on Environment and Development, 1987). In the following decades, the term sustainability has become increasingly seen as offering potential solutions to a wide range of challenges and problems from the global to the local scale 
across seemingly almost all walks of life. Barr (2008, p. xi), for example, claimed that "one of the most pressing and complex question of the early twentieth-first century" is "how to promote the behavioral shifts necessary for creating the sustainable society." Diesendorf (2000, p. 21) argued that "sustainability" can be seen as "the goal or endpoint of a process called sustainable development." Arguably the most widely used definition of sustainable development is "development that meets the needs of the present without compromising the ability of future generations to meet their own needs" (World Commission on Environment and Development 1987, p. 43), which Diesendorf (2000, p. 21) suggests "emphasizes the long term aspect of the concept of sustainability and introduces the ethical principle of achieving equity between present and future generations."

That said, sustainability is a contested concept and, as Aras and Crowther (2008, p. 435) have argued, "sustainability is a controversial topic because it means different things to different people." There is a family of definitions essentially based in and around ecological principles, and there are definitions which include social and economic development as well as environmental goals and which look to embrace equity in meeting human needs. At the same time, a distinction is often made between "weak" and "strong" sustainability, with the former being used to describe sustainability initiatives and programs developed within the existing prevailing economic and social system while the latter is associated with much more radical changes for both economy and society. Roper (2012, p. 72), for example, suggested that "weak sustainability prioritizes economic development, while strong sustainability subordinates economies to the natural environment and society, acknowledging ecological limits to growth."

These competing definitions of weak and strong definitions also reflect more fundamental questions about whether economic growth is compatible with sustainable development. In Securing the Future, the UK Labour Government's sustainable development strategy, launched in 2005, maintaining "high and stable levels of economic growth" was one of four aims alongside environmental protection, the prudent use of natural resources, and social progress, seemingly endorsing the compatibility of growth and sustainable development (UK Government, 2005, p. 15). Alternatively, some critics (e.g. Higgins, 2013) would suggest that continuing economic growth dependent as it is, on the seemingly ever increasing depletion of the earth's natural resources, is fundamentally incompatible with sustainability. Debates about compatibility seem certain to continue, but more recent UK Government policy on sustainable development has been "defined as job creation and economic growth" (Tewdwr-Jones, 2013, p. 49).

\section{CORPORATE SUSTAINABILITY AND SUSTAINABILITY REPORTING}

In basic terms, corporate sustainability is depicted as offering an alternative to the traditional business model based on growth and profit maximization in that it also emphasizes environmental protection, social justice and equity, and sustainable economic development. However, there is currently little detailed consensus in defining corporate sustainability and a number of meanings can be identified. On the one hand, there are definitions which seem to emphasize business continuity. Azapagic (2003, p. 303), for example, argued that corporate sustainability is an "an invaluable tool for exploring ways to reduce costs, manage risks, create new products, and drive fundamental internal changes in culture and structure." On the other hand, there are definitions that more explicitly embrace environmental and social goals and look to integrate these into a company's mission and core business strategy. Thus, corporate sustainability has been defined as "the discipline by which companies align decision-making about the allocation of capital, product development, brand 
and sourcing with the principles of sustainable development, in a resource-constrained world" (Global Association of Corporate Sustainability Officers, 2011).

The growing interest in and commitment to sustainability has seen the emergence of sustainability reporting across a wide range of companies and organizations. In essence, sustainability reporting is a broad term used to describe a company or an organization reporting on its environmental, social and economic impacts, and performance. For the Global Reporting Initiative (2011, p. 3) "sustainability reporting is the practice of measuring, disclosing, and being accountable to internal and external stakeholders for organizational performance towards the goal of sustainable development." In reviewing "the state of play in sustainability reporting within the European Union", van Wensen, Broer, Klein and Knofp (2011, p. 14) argued that "sustainability reporting is the provision of environmental, social and governance information within documents such as annual reports and sustainability reports."

In some ways sustainability reporting has become an "industry" in its own right, and a number of private companies and voluntary organizations offer sustainability reporting services and frameworks. The United Nations Environment Program (2013, p. 21), for example, identified a number of "reporting frameworks and protocols, reporting systems, standards and guidelines" and listed five organizations that have "gained the most widespread uptake," namely, the Global Reporting Initiative, the World Resource Institute, the Carbon Disclosure Project, the Climate Disclosure Standards Board and the United Nations Global Compact. However, the United Nations Environment Program (2013, p. 21) also reported that the Global Reporting Initiative "has become the leading global framework for sustainability reporting" and cited its comprehensive scope, its commitment to continuous improvement and its consensus approach as being important in contributing to its pre-eminence in the field. Originally founded in 1997, the Global Reporting Initiative reporting framework has progressively evolved from the original G1 Guidelines launched in 2000 to the current G4 Guidelines introduced in 2013. Within the Current G4 Guidelines materiality and external assurance are seen to be of central importance. Materiality is concerned with who is involved in identifying the environmental, social and economic issues that matter most to a company and its stakeholders and how this process is undertaken. External assurance is a set of procedures used to provide confidence in the accuracy and reliability of the reporting process.

A number of drivers are important in promoting the growth in sustainability reporting. Growing numbers of stakeholders are increasingly demanding greater disclosure from companies on how they are addressing environmental, social and governance issues, as well as other non-financial risks and opportunities. More specifically, Ernst and Young (2014, p. 6) argued that "one of the key drivers behind the increase in sustainability reporting is that to be meaningful, a sustainability strategy must be based on reliable concrete data. This can only be the case once the mechanisms and systems for reporting the facts are put in place." Hoekstra and Smits (2014, p. 6) have argued that "to steer our society toward a more sustainable future it is important that developments are measured" but also recognized that, while economic data is regularly collected, data on the environmental and social dimensions of sustainability is much less commonplace. At the corporate level, for example, while a growing number of companies include environmental and social performance indicator data in their sustainability reports, others currently do not and there is no consensus on the specification of indicators which currently renders comparative analysis virtually impossible.

More generally, the growth in corporate sustainability reporting and an increasing focus on materiality, external assurance, and measurement in the reporting process all reflect calls for greater transparency within sustainability reporting. In many ways, transparency can be seen as the 
key to sustainability, in that "once a company makes a commitment to transparency, the rest must follow" (CSR Reporting, 2011). Looking to the future greater transparency can be seen to be important in creating the momentum within companies to address environmental and social impacts and their associated challenges and, more generally, in driving corporate performance.

\section{FOOD AND DRINK WHOLESALING IN THE UK}

Wholesaling has been defined by a US-based knowledge source for marketing as "a distribution channel function where one organization buys products from supplying firms with the primary intention of redistributing to other organizations" (KnowThis.com, 2016) and as "the sale and distribution of goods to users other than end consumers" (Investopedia, 2016). Within the UK, wholesaling is a significant sector of the economy generating an annual turnover of some GBP 900 billion and employing some one million people (Federation of Wholesale Distributors, 2014). Food and drinks wholesalers buy products in bulk from producers, manufacturers or processors and provide a supply chain solution for a wide range of businesses, particularly small independent retail outlets, convenience stores and hotels, public houses, restaurant, cafes schools, and canteens. In 2014, the Federation of Wholesale Distributors reported that food and drinks wholesalers supplied over 400,000 businesses, had a combined turnover of GBP 30 billion per annum, greater than any UK supermarket group other than the market leader Tesco, employed some 66,000 people and generated GBP 2.8 billion of gross added value to the UK economy (Federation of Wholesale Distributors, 2014).

In essence, the role of food and drinks wholesalers is to buy products in bulk and to sell and distribute them to smaller companies at cheaper prices than the smaller companies could negotiate from the producers, manufacturers and processors. Two principal systems of wholesale distribution can be identified, namely, cash and carry businesses and delivered good businesses though some companies employ a combination of both systems. In the former, businesses visit large depots to buy and collect goods, while in the latter the wholesalers offer a delivery service to their retail and catering customers. Generally, delivered goods wholesalers have a number of large depots, located on a regional basis from which the wholesalers deliver via their own haulage fleet. Delivered good wholesaling can be further divided into delivered grocery operations and delivered food service operations. While the food and drink wholesaling market is smaller than its retail counterpart, in providing a link between manufacturers and producers on the one hand and retailers and caterers on the other, food and drinks wholesalers have the potential to play an important role in promoting sustainability.

Food and drink wholesaling includes a wide range of operators, but a small number of large companies are the dominant players. Booker is the UK's largest cash and carry wholesaler with a nationwide network of 172 depots, stretching from Inverness to Brighton and from Haverford West to Great Yarmouth with 19 sites in Greater London. The depots vary in size but offer an extensive range of up to 20,000 branded and private label products which includes grocery products, fresh and frozen food products, wine, beer and spirits, tobacco, pet foods, a range of catering products and catering equipment, and cleaning products. Bestway/Batleys claim to have created the "cash and carry" concept with the opening of a depot in Huddersfield in 1958, when Batleys traded under the banner "Come and Get It." In 2005, Batleys was acquired by Bestway to form the second largest cash and carry wholesale trader in the UK and the company currently trades from 50 depots. These depots are located throughout much of the UK, although they are concentrated in the major population centers of Greater London, the West Midlands, Lancashire and Yorkshire, and 
the Scottish Central Belt, and many depots also offer a delivered service. Blakemore, originally founded as a retail business in Wolverhampton in 1917, operates from 14 cash and carry depots; following its acquisition of Lowries Cash and Carry and the BA Cash and Carry companies in 2013 and 2014 respectively, it became the third largest cash and carry operator in the UK. The company's depots are concentrated in the North and Midlands of England, and its product range includes fresh, ambient, chilled, and frozen foods. In contrast to these national networks, Dhamecha claims to be "London's Leading Cash and Carry"; it trades from seven depots in Greater London although in 2015 it acquired a depot in Leicester.

The leading players within the delivered grocery sector are P\&H McLane, the Spar wholesalers, and Musgrave. Palmer and Harvey McLane have grown steadily through both organic growth and acquisition to become the UK's largest delivered food and drinks wholesaler. The company serves some 90,000 retail outlets from 15 regional depots, it operates a fleet of over 1,000 vehicles and offers some 14,000 ambient, chilled and frozen product lines. Spar, the largest symbol group convenience store operator in the UK, is served by six wholesalers which operate on a defined geographical basis. The majority of these wholesalers solely serve Spar stores but some, including Blakemore, provide a delivered service to other customers. James Hall \& Co, for example, originally founded in Southport in 1863, serves over 500 Spar stores in the North of England. Appleby Westward, based in Saltash, serves Spar stores from Portsmouth to Helston and as far north as Bristol. While Musgrave has international operations, within the UK its wholesale operations serve a range of linked retail outlets in Northern Ireland and it also has cash and carry operations. Delivered food service is the least concentrated element within food and drink wholesaling, but two companies, namely Brakes and Bidvest, have a $30 \%$ market share and both companies have grown through acquisition during recent years.
Brakes, which was initially established as a family firm in 1958, is a major supplier to public houses, hotels, schools, and care homes throughout the UK and employs over 10,000 people. Bidvest operates from 23 depots and three regional distribution centers across the UK; its product offer includes essentials such as baked beans, cooking sauces, and jams, as well as a wide range of prepared meals.

\section{METHOD OF ENQUIRY}

In order to review the sustainability agendas and achievements reported by the UK's leading food and drinks wholesalers, the authors selected the leading companies, namely, Booker, Bestway/Batleys, Costco, Blakemore, Parfetts, Dhamecha, Palmer \& Harvey, Musgrave, the five Spar wholesalers (John Henderson, C.J. Lang and Sons, James Hall and Co., Blakemore, and Appleby Westward) Brakes and Bidvest, as identified by the Institute for Grocery Distribution (2015). As the leading players within the UK's wholesale food and drinks marketplace, the selected wholesalers might be seen to reflect contemporary approaches to sustainability within the sector and be keen to publicize their sustainability initiatives to a wide audience.

Businesses employ a variety of methods to report on sustainability including "product labels, packaging, press/media relations, newsletters, issue related events, reports, posters, flyers, leaflets, brochures, websites, advertisements, information packs and word-of mouth" (European Commission Directorate-General for Enterprise 2005, p. 5), but publication on corporate websites has become the most popular and the most accessible reporting mechanism (Morhardt, 2009). With this in mind, the authors undertook a digital search of each of the selected wholesale companies' corporate websites using the key word "sustainability" in January 2016; they used Google as the search engine and chose the most recent reports and information published by the selected wholesalers. 
A number of authors (Newell, 2008; De Grobois, 2016) have employed content analysis to interrogate corporate websites and sustainability reports. However, in this paper the authors took the decision to tease out the key themes and narratives by a close inspection of the most recently published sustainability reports and the information on the selected wholesalers' corporate websites. In taking this decision, the authors were minded of the need to discover, rather than to attempt to precisely measure, the companies' approach to sustainability. While the precise pattern of search and navigation varied from one wholesaler to another, the authors were essentially guided by loosely grounded theory in that they selected and grouped sustainability themes and issues identified on the wholesalers' corporate websites. The information obtained through this search and interrogation process provided the empirical information for this paper. The aim of the paper is not to attempt offering a systematic and detailed comparative analysis and evaluation of the selected wholesalers' approaches to sustainability, and the specific examples and quotations are employed primarily for illustrative rather than for comparative or analytical purposes. Unless otherwise specifically cited, all the quotations in the paper are from the wholesalers' corporate websites.

In discussing the reliability and validity of information obtained from the Internet, Saunders, Lewis and Thornhill (2009) emphasized the importance of the authority and reputation of the source and the citation of a specific contact person who can be approached for additional information. In surveying the selected food and drink wholesalers, the authors were satisfied that these two conditions were met. At the same time, the authors openly recognize that the approach chosen has its limitations in that there are issues in the extent to which a company's public statements fulsomely, and in detail, reflect strategic corporate thinking and whether or not such pronouncements may be little more than thoughtfully constructed public relation exercises. However, the authors believe that their approach offers an accessible window and a sufficiently robust approach for the purposes of the present exploratory study.

\section{FINDINGS}

The findings revealed marked variations in the extent to which the selected wholesalers publicly reported and provided information on their sustainability strategies and achievements. Five of the wholesalers - namely, Bestway/ Batley, Costco, Blakemore, Musgrave, and Bidvest - posted dedicated sustainability reports and one wholesaler, Booker, published a short sustainability report within its annual company report. Two of the wholesalers, Brakes and Dhamecha, posted some information on their approach to sustainability (although the material posted by Dhamecha was minimal) and two of the wholesalers, Parfetts and Palmer\&Harvey (which are both privately owned companies), posted no information on sustainability. The approach taken by the five Spar wholesalers partly mirrored the more general reporting pattern in that, while Blakemore posted a sustainability report related to its Spar activities, the other four others posted some limited information on sustainability. The specific websites of the companies which posted reports or information on sustainability are shown in Table 1 (see appendix).

All the selected wholesales, with the sole exception of Dhamecha, which posted reports or information on sustainability, recognized that their business activities have an impact on the environment, as well as on the communities and the economies in which they operate. Some of the wholesalers claimed to have integrated or to be integrating sustainability into their business models. Echoing the most widely used definition of sustainability, Brakes, for example, argued that "safeguarding the future for generations to come is part of our corporate DNA." Musgrave argued that "developing a business that helps support the social, econom- 
ic and environmental health of urban and rural communities is an absolute priority-it goes to the very heart of what we do" and claimed that its approach to sustainability involves commitments "to look after its people and customers", "to minimize its impact on the environment" and to make "a positive contribution to people's lives, to their communities and to society as a whole." In a similar vein, Booker reported recognizing the social and environmental responsibilities arising from its business operations and, more specifically, stressed its recognition of its corporate obligation to carefully consider how it uses natural resources. Blakemore emphasized its commitment to promote health and safety and environmental protection and to prevent pollution throughout the company.

More specifically, the selected wholesalers reported and provided information on a range of environmental, social, and economic issues and agendas. A number of environmental issues are addressed, including climate change and greenhouse gas emissions, energy consumption and energy efficiency, logistics, waste management and recycling, sustainable sourcing, site development, and building design. Costco, for example, reports on its initiatives in tracking and reporting on its greenhouse gas footprint and emphasizes its commitment to maintaining its carbon footprint growth to less than its company sales growth. Under the banner "We're Tackling Climate Change", Bidvest reported on its initiatives to increase energy efficiency at a number of its depots. Between 2011 and 2015, Bestway/Batleys reported on reducing its carbon footprint by over $70 \%$ despite adding two new depots, extending a third depot and opening a new chilled distribution centre during that period of time. Booker emphasized that the more efficient use of energy, minimizing greenhouse gas emissions and monitoring energy consumption were key components in its evolving environmental programs.

A number of the wholesalers reported on pursuing energy efficiencies in their logistics operations. Musgrave, for example, reported on trying to avoid and to minimize journeys whenever possible, on its adoption of route planning and scheduling systems designed to produce maximum efficiency and on its widespread practice of backhauling from suppliers to avoid vehicles returning empty to their depots. In a similar vein, Bidvest reported on improving operational efficiency in its transport operations with the emphasis being on using the most appropriate technology available and on reducing the total kilometers travelled on each delivery route. In managing its car fleet, Bestway/Batleys emphasized its commitment to "having a green car fleet", as evidenced by its purchase of "hybrid vehicles with low carbon dioxide emissions."

In reporting on its approach to waste prevention, Booker claimed it was continually working to prevent the generation of waste and to redistribute surplus, to increase recycling and to divert waste away from landfill. Each of the company's depots and distribution centers is involved in recycling paper, plastic, cardboard, metal, and wood from pallets. During 2014/2015, the company reported increasing the volume of waste recycled and sent to recovery centers by $11 \%$ and reduced waste sent to landfill by $29 \%$. The company also reported working with suppliers and customers to reduce waste across the supply chain. Blakemore reported that a comprehensive waste management system was in place across its entire food service business, that waste was segregated into food, cardboard and plastic streams and that over $80 \%$ of all waste was recycled. Bidvest reported reducing total mains water consumption by $2.2 \%$ in 2015 and outlined the company's plans to install water meters at all of its sites and to monitor these meters remotely, thus identifying potential opportunities to further reduce consumption.

Some of the wholesalers reported on their commitment to sustainable sourcing. Brakes, for example, claimed that sustainable sourcing was an important consideration when sourcing products for its customers; more specifically, the company stressed its commitment to animal welfare and farm assurance schemes, the 
protection of the fishing industry and fish stocks and said that its buyers and suppliers took environmental elements into consideration at every stage of the procurement and supply chain process. More specifically, Brakes recognized the threat posed by overfishing, describing it as a "huge global challenge, with unsustainable practices leading to the depletion of stocks which threatens livelihoods and marine ecosystems" and reported being the first food service wholesaler in the UK to receive Marine Stewardship Council certification. Costco reported on a number of initiatives in its approach to sustainable practices in site development and building design. These included computerized buildings management systems to maximize efficiency, the use of building insulation materials, the installation of energy efficient lighting systems, and the construction of bio-retention rain gardens.

In addressing the social dimensions of sustainability being pursued by the selected wholesalers, a number of themes can be identified; these include health and wellbeing, links with local communities, charitable donations, as well as diversity, equality of opportunity, health and safety and employee training, and staff development within the work environment. Bestway/ Batleys, for example, reported on its support for initiatives to help improve public health and on signing up to "The Public Health Responsibility Deal." Bestway/Batleys reported that its public health targets which include its work with suppliers to improve its offer on healthy products, its initiatives to reduce salt and artificial additives in its own label ranges and on its commitment to the provision of nutritional information on its own label packaging. As one of the company's "sustainability priorities", Bidvest reported on its commitment to "providing real choice through more sustainable and healthy eating products for our customers" and to "delivering the right nourishment for young and old."

Blakemore reported on the ways it sought to make a positive contribution to the community and on the Blakemore Foundation, which promotes a variety of charitable fund raising activities, volunteering amongst its workforce, and collaborative working on regeneration projects. Musgrave reported on its commitment to "building vibrant communities" and on the company's initiatives in "inspiring pride in place" and encouraging volunteers to help improve the environment in the communities in which they live and work. Bestway/Batleys also emphasized its role in supporting communities within the UK, notably through the work of the Bestway Foundation, which undertakes various health and education charitable activities, and the company's support for communities overseas and, more particularly, for natural disaster rehabilitation and relief efforts. Booker reported on its donations of surplus food to local homeless charities from the company's business and distribution centers.

All the selected wholesalers emphasized their commitment to their employees. Bidvest, for example, reported on its approach to "people development", namely, that "our goal is to grow a pipeline of talented people to provide us with a dedicated team who enjoy working for us and want to share in the successes of our future and that of our customers." Furthermore, Bidvest emphasized looking to create opportunities for its employees to improve their skills base and asserted its belief that all of its employees should feel valued and have the opportunity for self-development; the company also reported that it was exploring employee development pathways across a number of business functions with a specific focus on apprenticeship schemes. Brakes reported on its commitment to learning and development opportunities, diversity, flexible working, employee engagement, effective employee communication, and on the promotion of a positive inclusive culture within the company. Many of the wholesalers also reported on promoting health and safety within the workplace. Bestway/Batleys, for example, reported on its commitment to the maintenance and continuing improvement of the health, safety, and welfare of its employees. 
Economic issues generally received more limited coverage in the reports and information the selected wholesalers posted on sustainability but included employment creation, supplier relationships focused on ethical trading and Fair Trade, and local sourcing. Some of the wholesalers emphasized their role in providing employment opportunities. Brakes, for example, reported that it employed over 10,000 people, and the corresponding figures for Blakemore and Bidvest were 7,900 and 3,200 respectively. Dhamecha simply claimed to enhance the economic development of the communities in which it operates. Musgrave reported it aimed to be the preferred place of work and that the company looked to provide people of all ages and circumstances with an opportunity for betterment.

Brakes reported on its "ethical trading culture" and that "our policy is to purchase goods produced in conditions" that do not involve "abuse or exploitation." Furthermore, Brakes reported that the company expected all of its suppliers to commit to work towards full compliance with labor standards, based on those set by the Ethical Trade initiative which reflect the International Labor Organization conventions. Booker reported continuing to expand its range of catering products certified as being Fair Trade and that during 2014-2015 the company contributed the equivalent of some GBP 65,000 through Fair Trade premiums to coffee growers.

Some of the wholesalers stressed their commitment to local sourcing, but the conception of what is deemed to be "local" seems to vary. Musgrave promised that the company would develop a strategic approach to developing a local supplier base and that it would look to champion local food by "developing and investing in a vibrant local supply base." John Henderson, one of the Spar wholesalers, claimed it was "proud to support local suppliers with over 75\% of our fresh products sourced locally." Bestway/ Batleys reported working with over 300 local and regional suppliers across its fresh, chilled and frozen food ranges and on its commitment to the development of sustainable business models for local businesses. Bidvest claimed "we like to do our bit locally" and that "we're big on British." More specifically, Bidvest reported continuing to focus on British products and to refine its quality assurance processes to enable the company to ascertain and guarantee the percentage of British ingredients in its range of core products. Brakes also emphasized its commitment to British sourcing and reported that the company currently offered over 2,000 British own brand products with "key ingredients sourced, produced and packed in the UK."

\section{DISCUSSION}

While the findings revealed that the majority of the UK's leading food and drink wholesalers publicly recognized the impacts their businesses have on the environment, on society, and on the economy, there are marked variations in the extent and detail of the reporting process. While a number of the selected wholesalers posted dedicated sustainability reports, others posted some information on their approach to sustainability on their corporate websites, although the nature and extent of this information varied considerably, whereas others posted no information on sustainability. This is not a problem per se since companies have no statutory obligation to report on sustainability; but in reviewing the wholesalers' current approach to sustainability, three sets of issues merit discussion and reflection.

Firstly, there is a set of issues about the way the selected wholesalers reported and presented information on their approach to sustainability. Each of the wholesalers reported or provided information on sustainability in their own individual ways but they often included a brief narrative on sustainability agendas and achievements, occasionally illustrated with limited statistical information, images, simple graphs, and diagrams. Cameo case studies were also occasionally used to illustrate general themes. The authors have chosen not to present or repro- 
duce any of this illustrative material in the paper because it could potentially be seen as an unrepresentative sample, which did not capture the diversity of presentation styles and modes. However, this illustrative material is available on the corporate websites listed in Table 1. The wholesalers' generally idiosyncratic approach to reporting and providing information on sustainability makes it difficult to make any meaningful comparisons between wholesalers or to attempt any evaluation of the progress wholesalers are making towards the achievement of sustainability targets at the national level. While some of the selected wholesalers provided albeit limited information on achievements in pursuing sustainability agendas, the main weight of the reporting process was generally on the agendas. As such, the wholesalers' current approach to sustainability reporting might be seen to be largely, though not exclusively, aspirational.

The wholesalers which posted dedicated sustainability reports made no reference to generic guidelines, such as the Global Reporting Initiative (GRI) framework. This framework, now widely used throughout the world's business community, is designed to provide a methodology for measuring and reporting sustainability impacts and performance. More specifically, any consideration of materiality was conspicuous by its absence and only one of the selected wholesalers, namely Bidvest, commissioned any independent external assurance of its sustainability report. As such, the sustainability reports and information posted by the selected wholesalers might be seen to represent the executive management's approach to sustainability, rather than the potentially wider sustainability agendas and concerns of the company's stakeholders. At the same time, the wholesalers' general failure to commission external assurance can be seen to reduce the credibility and the reliability of their sustainability reporting processes: That said, the UK's leading wholesalers are large and dynamic organizations, and capturing and storing comprehensive information and data throughout the supply chain in a variety of geographical locations and then providing access to allow external assurance is a challenging and a potentially costly venture. Currently, the majority of the selected wholesalers choose not to publicly pursue such an exercise.

While the leading wholesalers are important players in food and drinks distribution within the UK, they currently lag a long way behind their retail counterparts in their approach to sustainability. By way of comparison, all the UK's leading retailers produce dedicated annual sustainability reports (Jones, Hillier \& Comfort, 2013); some of them embrace materiality and commission independent external assurance (Jones, Comfort \& Hillier, 2015b). This may reflect the fact that the UK's leading retailers are larger and have more mature management structures and are possibly more attuned to leading edge management thinking and practice than their wholesale counterparts. At the same time, it may also reflect the fact that the leading retailers have a high visibility on the High Street and in edge-of-town and out-of-town retail parks, whereas "many of the largest and most important wholesalers are largely unknown to final consumers" (Armstrong, Kotler, Harker \& Brennan, 2012, p. 394). Therefore, the leading food and drink wholesalers may currently feel less pressure to publicly demonstrate their accountability, to their customers, to government, and to the media than their retail counterparts.

Secondly, there are issues about the way in which the selected wholesalers implicitly and collectively define sustainability and construct their sustainability agendas. While the majority of the selected wholesalers emphasized their commitment to sustainability, they can be seen, both individually and collectively, to have constructed a specific definition of the concept. This definition is primarily built around business efficiency and cost savings and is driven more by business imperatives than by a concern with sustainability. While many of the environmental agendas addressed by the selected wholesalers are designed to reduce energy, water consump- 
tion, and waste emissions, for example, they also reduce costs. In a similar vein, the wholesalers' commitments to their employees focusing for example, upon good working conditions, health and safety at work, and training all help to promote stability, security, loyalty, and efficiency within the workforce.

These business imperatives are perhaps most pointedly expressed in the sustainability report posted by Costco. In addressing climate change, for example, Costco reported "factors associated with climate change could adversely affect our business" and that increased government regulation "to limit carbon dioxide and other greenhouse gas emissions may result in increased compliance costs and legislation or regulation affecting energy inputs that could materially affect our profitability." Costco further reported that "climate change could affect our ability to procure needed commodities at costs and in quantities we currently experience." In addressing its responsibilities within the workplace, Bestway/Batleys expressed its belief that "our business performance depends upon the commitment, determination and creativity of our people" and "for this reason we encourage the continuous development of employees through comprehensive training programs."

The selected wholesalers might thus be seen to have constructed sustainability agendas, which are driven primarily, though not necessarily exclusively, by their own commercial interests. The accent is on efficiency gains across a wide range of economic, social, and environmental issues, rather than on maintaining the viability of natural ecosystems and reducing demands on finite natural resources. More generally, Aras and Crowther (2009, p. 280) argued that corporate sustainability reporting has the effect of obscuring "the effect of corporate activity upon the external environment and the consequent implications for the future" and that "one of the effects of persuading that corporate activity is sustainable is that the cost of capital for the firm is reduced as investors are misled into thinking that the level of risk involved in their investment is lower than it actually is." In a similar vein, Banerjee (2008, p. 143) has argued that "despite their emancipatory rhetoric, discourses of corporate citizenship, social responsibility and sustainability are defined by narrow business interests and serve to curtail the interests of external stakeholders."

Thirdly, there are broader issues around the underlying tensions between sustainability and economic growth. With an eye to the future, the sustainability reports and information posted by a number of the selected wholesalers are couched within the idiom of continuing growth and business expansion. Brakes, for example, reported on its continuing growth, saying that during 2014 the company "engaged with over 30 suppliers to collaborate on new deals for delivering growth together" and that the company was "unlocking future growth in fresh food." Blakemore stressed its "commitment to growth" and suggested that its sustainability report "demonstrates how we intend to make this growth sustainable" without defining what sustainable growth means to the company. In some ways, this reflects the distribution sector's general position as epitomized by Sir Terry Leahy, the then Chief Executive Officer of Tesco, in his "Foresight" contribution at the start of The Global Coca Cola Retailing Research Council Forum (2009, p. 16) report. He argued that, at that time, his company was "seeking to create a movement which shows that it is possible to consume, to be green and to grow." Such an approach is rooted in the general belief that continuing economic growth will be accompanied by the more efficient use of resources. This trend, which is seen as either relative or absolute decoupling (relative decoupling refers to using fewer resources per unit of economic growth while absolute decoupling refers to a total reduction in the use of resources), underpins many conventional definitions of sustainability and the vast majority of current corporate sustainability strategies and programs. However, Weidmann and others (2015, p. 6271) argued that "achievements in decoupling in advanced 
economies are smaller than reported or even non-existent", and this, in turn, may be seen to ultimately undermine the concept of sustainable growth.

The concept of sustainable consumption, which Cohen (2005) has described as "the most obdurate challenge for the sustainable development agenda" is conspicuous by its absence in the sustainability reports and information posted by the leading wholesalers. In arguing that "Europe must take the lead in exploring a new model of consumption which does not compromise the needs of others or of future generations, nor damage the environment", the European Environment Agency (2012) branded "unsustainable consumption" as "the mother of all environmental issues." That said, within the UK there is little consumer appetite for sustainable consumption, and here the European Commission's $(2012$, p. 9) recognition that "sustainable consumption is seen by some as a reversal of progress towards greater quality of life", in that "it would involve a sacrifice of our current, tangible needs and desires in the name of an uncertain future", certainly resonates. This view is supported by Reisch, Spash and Bietz (2008, p. 2), who argued that although moving towards sustainable consumption is a major policy agenda, "growth of income and material throughput by means of industrialization and mass consumerism remains the basic aim of western democracy." More critically, Castro (2004) has questioned the very possibility of sustainable development under capitalism and argued that economic growth relies upon the continuing and inevitable exploitation of both natural and social capital.

\section{CONCLUSION}

The majority of the UK's leading food and drink wholesalers, either publicly reported on, or provided information on, their commitments to sustainability. A minority either explicitly or implicitly argued that, by integrating sustainability into their businesses, they are better placed to provide long-term growth and financial security for all stakeholders and to enhance their market position and reputation. However, the authors argue that the leading food and drink wholesalers' definitions of, and commitments to, sustainability can be interpreted as being driven as much by business imperatives as by any fundamental commitments to sustainability. Thus, the accent is upon making efficiency gains across a wide range of economic, social, and environmental issues and not on maintaining the viability and integrity of natural ecosystems and on reducing demands on finite natural resources. As such, the UK's leading wholesalers are, at best, pursuing a "weak" rather than a "strong" model of sustainability. More critically, the authors suggest that the leading food and drink wholesalers' commitments to sustainability are couched within existing business models, centered on continuing growth and consumption, and that current policies might be viewed as little more than genuflections to sustainability. This echoes Roper's (2012, p. 72) belief that weak sustainability represents "a compromise that essentially requires very little change from dominant economic driven practices but effectively works to defuse opposition, increase legitimacy and allow business as usual." The UK's leading food and drink wholesalers are thus effectively and conveniently ignoring the idea that present patterns of consumption may simply be unsustainable in the long term. 


\section{References}

1. Aras, G., \& Crowther, D. (2008). Governance and Sustainability: An investigation into the relationship between corporate governance and corporate sustainability. Management Decision, 46(3), 433-448.

2. Aras, G., \& Crowther, D. (2009). Corporate Sustainability Reporting: A Study in Disingenuity?. Journal of Business Ethics, 87(1), 279-288.

3. Armstrong, G., Kotler, P., Harker, M., \& Brennan, R. (2012). Marketing: An Introduction. Harlow: Pearson.

4. Azapagic, A. (2003). Systems Approach to Corporate Sustainability. Transactions of the Institute of Chemical Engineers, 81, 303-316.

5. Banerjee, S. B. (2008). Corporate Social Responsibility: The Good, the Bad and the Ugly. Critical Sociology, 34(1), 51-79.

6. Baron, S., Davies, B., \& Swindley, D. (1991). Macmillan Dictionary of Retailing. London: Macmillan.

7. Barr, S. (2008). Environment and Society: Sustainability, Policy and the Citizen. Aldershot: Ashgate.

8. Castro, C. (2004). Sustainable Development: Mainstream and Critical Perspectives. Organisation and Environment, 17(2), 195-225.

9. Chkanikova, O., \& Mont, O. (2015). Corporate Supply Chain Responsibility: Drivers and Barriers for Sustainable Food Retailing. Corporate Social Responsibility and Environmental Management, 22(2), 65-82.

10. Cohen, M. J. (2005). Sustainable consumption in national context; an introduction to the symposium. Available at: http://ejournal.nbii.org/archives/vol1iss1/0410-008.cohen.htmll

11. CSR Reporting (2011). Transparency is the key to Sustainability. Available at: http://csr-reporting. blogspot.co.uk/2011/09/transparency-is-key-to-sustainability.html

12. De Grosbois, D. (2016). Corporate Social Responsibility Reporting in the Cruise Tourism Industry: A Performance Evaluation using a New Institutional Theory Based Model. Journal of Sustainable Tourism, 24(2), 245-269.

13. Diesendorf, M. (2000). Sustainability and Sustainable Development. In: D. Dunphy, J. Beneveniste, A. Griffiths \& P. Sutton (eds.). Sustainability: The corporate challenge of the $21^{\text {st }}$ century (pp. 19-37). Sydney: Allen and Unwin.

14. Ernst and Young (2014). Sustainability Reporting: The time is now. Available at: http://www.ey.com/ Publication/vwLUAssets/EY_Sustainability_reporting_-_the_time_is_now/\$FILE/EY-Sustainability-reporting-the-time-is-now.pdf

15. EuroCommerce (2014). Wholesale: Job Engine at the Centre of Europe's Economy. Available at: http:// www.eurocommerce.eu/media/78569/eurocommerce_brochure_wholesales_v2_150223.pdf

16. European Commission (2012). Policies to Encourage Sustainable Consumption. Available at: http:// ec.europa.eu/environment/archives/eussd/pdf/report_22082012.pdf

17. European Commission Directorate-General for Enterprise (2005). A Guide to Communicating about CSR. Available at: http://ec.europa.eu/enterprise/policies/sustainable-business/files/csrsme/communication_guide_en.pdf

18. European Environment Agency (2012). Unsustainable consumption - the mother of all environmental issues. Available at: http://www.eea.europa.eu/highlights/unsustainable-consumption-2013-the-mother

19. Federation of Wholesale Distributors (2014). The Whole Story: Wholesale Distribution, the High Street, Consumers and Society. Available at: http://www.igd.com/Research/Retail/Wholesaling-and-foodservice/4114/UK-Wholesale-Market-Overview/

20. Global Association of Corporate Sustainability Officers (2011). Defining and developing the corporate sustainability professional. Available at: http://www.gacso.org/Resources/Documents/defining\%20the\%20corporate\%20sustainability\%20professional.pdf 
21. Global Reporting Initiative (2011). Sustainability Reporting Guidelines. Available at: https://www. globalreporting.org/resourcelibrary/G3.1-Guidelines-Incl-Technical-Protocol.pdf

22. Gruber, U. (2013). Sustainability: a Cultural History. Cambridge: Green Books.

23. Higgins, K. L. (2013). Economic growth and sustainability - are they mutually exclusive. Available at: https://www.elsevier.com/connect/economic-growth-and-sustainability-are-they-mutually-exclusive

24. Hoekstra, R., \& Smits, J. P. (2014). Reporting on sustainable development at national, company and product levels: The potential for alignment of measurement systems in a post-2015 world. Available at: http://measurewhatmatters.info/wp-content/uploads/2014/10/Alignment-of-SD-reporting-atnational-company-and-product-levels-CBS-TSC-GRI.pdf

25. Ilbery, B., \& Maye, D. (2005). Food supply chains and sustainability: evidence from specialist food producers in the Scottish/English borders. Land Use Policy, 22, 331-344.

26. Institute for Grocery Distribution (2015). UK Wholesale Market Overview. Available at: http:// www.igd.com/Research/Retail/Wholesaling-and-foodservice/4114/UK-Wholesale-Market-Overview/

27. International Union for Conservation of Nature and Natural Resources (1980). World Conservation Strategy. Available at: https://portals.iucn.org/library/efiles/documents/WCs-004.pdf

28. Investopedia (2016). Wholesaling. Available at: http://www.investopedia.com/terms/w/wholesaling.asp

29. Jones, P., Comfort, D., \& Hillier, D. (2015b). Materiality in Corporate Sustainability Reporting, Within UK Retailing. Journal of Public Affairs, 16, 81-90.

30. Jones, P., Comfort, D., \& Hillier, D. (2015a). Sustainability and the UK's Leading Retailers. Market-Tržište, 27(1), 93-111.

31. Jones, P., Comfort, D., Hillier, D., \& Eastwood, I. (2005). Corporate Social Responsibility: A Case Study of the UK's Leading Food Retailers. British Food Journal, 10(6), 423-435.

32. Jones, P., Hillier, D., \& Comfort, D. (2013). In the Public Eye: Sustainability and the UK's Leading Retailers. Journal of Public Affairs, 13(1), 3-40.

33. KnowThis.com (2016). What is Wholesaling. Available at: http://www.knowthis.com/wholesaling/ what-is-wholesaling

34. Morhardt, J. E. (2009). Corporate Social Responsibility and Sustainability Reporting on the Internet. Business Strategy and the Environment, 19(7), 436-452.

35. Newell, G. (2008). The strategic significance of environmental sustainability by Australian-listed property trusts. Journal of Investment Property and Finance, 37(2), 205-209.

36. Newman, A. J., \& Cullen, P. (2002). Retailing: Environment and Organisation. London: Thomson Learning.

37. Reisch, L., Spash, C. L., \& Bietz, S. (2008). Sustainable Consumption and Mass Communication: A German Experiment. Available at: http://www.csiro.au/files/files/pm9m.pdff

38. Roper, J. (2012). Environmental risk, sustainability discourses and public relations. Public Relations Inquiry, 1(1), 69-87.

39. Saunders, M., Lewis, P., \& Thornhill, A. (2009). Research Methods for Business Students. Harlow: Prentice-Hall.

40. Steedman, P., \& Falk, T. (2009). From A to B: A Snapshot of the UK Food Distribution System. Available at: http://www.foodethicscouncil.org/uploads/publications/Snapshot(web)_0.pdf

41. Tewdwr-Jones, M. (2013). LEPs and Planning: More than mechanisms of convenience. Available at: http://www.ncl.ac.uk/curds/assets/documents/wherenext.pdf

42. The Global Coca Cola Retailing Research Council Forum (2009). Sustainability in Retailing. Available at: http://www.coke.net/app/public/ccrrcgrp/CCRRC_GLOBAL.pdf 
43. UK Government (2005). Securing the Future; UK Government Sustainable Development Strategy. Available at: https://www.gov.uk/government/uploads/system/uploads/attachment_data/ file/69412/pb10589-securing-the-future-050307.pdf

44. United Nations Environment Program (2013). Frequently Asked Questions on Corporate Sustainability Reporting. Available at: https://www.globalreporting.org/resourcelibrary/GoF47Para47-FAQs. pdf

45. van Wensen, K., Broer, W., Klein, J., \& Knofp, J. (2011). The State of Play in Sustainability Reporting in the European Union. Available at: http://ec.europa.eu/social/main.jsp?langld=en\&catld=89\&newsId $=1013$

46. Wiedmann, T. O., Manfred, S., Lenzen, M., Moran, D., Suh, S., West, W., \& Kanemoto, K. (2015). The Material Footprint of Nations. Proceedings of the National Academy of Sciences, 112(20), 6271-6276.

47. World Commission on Environment and Development (1987). Our Common Future. Available at: http://www.un-documents.net/ocf-02.htm

48. Yakovleva, N., Sparks, J., \& Sloan, W. T. (2010). Sustainability indicators for the food supply chain. In: U. Sonesson, J. Berlin \& F. Ziegler (eds.). Environmental Assessment and Management in the Food Industry (pp. 297-329), Oxford: Woodhead Books.

\section{Appendix}

TABLE 1: Leading UK Wholesalers: Company Web Sites on Sustainability

\begin{tabular}{|c|c|}
\hline Booker & $\begin{array}{l}\text { http://www.bookergroup.com/ /media/Files/B/Booker-Group/ } \\
\text { pdf/investor-centre/reposts-presentations/rp2015/annual-report- } \\
\text { accounts-2015.pdf }\end{array}$ \\
\hline Bestway/Batley & https://www.bbfoodservice.co.uk/files/Corporate-Responsibi_ssaf8k.pdf \\
\hline Costco & $\begin{array}{l}\text { http://www.google.co.uk/url?sa=t\&rct=j\&q=\&esrc=s\&source=web\&c- } \\
\text { d=1\&cad=rja\&uact=8\&ved=0ahUKEwjukOOTyMzNAhXMJcAKHcPQA- } \\
\text { RoQFggfMAA\&url=http\%3A\%2F\%2Fphx.corporate-ir.net\%2FExternal. } \\
\text { File\%3Fitem\%3DUGFyZW50SUQ9Mjc3MzQ3fENoaWxkSUQ9LTF8VHIwZ- } \\
\text { T0z\%26t\%3D1\&usg=AFQjCNHD40Kba_1c }\end{array}$ \\
\hline Blakemore & http://www.afblakemore.com/pdf/Corporate-Responsibility-Report-2014.pdf \\
\hline Dhamecha & http://www.dhamecha.com/group \\
\hline Musgrave & $\begin{array}{l}\text { http://www.musgravesustainability.com/en/sustainability_in_action/ } \\
\text { latest_report.php }\end{array}$ \\
\hline Bidvest & $\begin{array}{l}\text { http://www.musgravesustainability.com/en/sustainability_in_action/ } \\
\text { latest_report.php }\end{array}$ \\
\hline Brakes & http://www.brakesgroup.com/responsibility/ \\
\hline \multicolumn{2}{|l|}{ Spar Wholesalers: } \\
\hline John Henderson & http://www.henderson-group.com/ \\
\hline C. J. Lang \& Sons & https://www.cjlang.co.uk/about-us/community.aspx \\
\hline Blakemore & http://www.afblakemore.com/pdf/Spar-CR-Review-2014.pdf \\
\hline James Hall \& Co. & https://www.jameshall.co.uk/index.php/community/our-stores/ \\
\hline Apple by Westward & http://www.swspar.com/about/about-appleby-westward-home.php \\
\hline
\end{tabular}

